\title{
Phage Induction of Lysogenic Rhizobium leguminosarum biovar trifolii in both the Free-living and the Symbiotic Form
}

\author{
By TOSHIKI UCHIUMI, * YASUHIRO ONO, MIKIKO ABE AND \\ SHIRO HIGASHI \\ Department of Biology, Faculty of Science, Kagoshima University, Kagoshima 890, Japan
}

(Received 17 April 1989; revised 10 July 1989; accepted 10 August 1989)

\begin{abstract}
A lysogenic strain, Rhizobium leguminosarum biovar trifolii $\mathrm{UK}-1: \phi \mathrm{U}$, was isolated from a wild white clover nodule. It was symbiotically effective on white clover. A lysogenic phage (U-mole) was induced from this strain by treatment with either UV irradiation or mitomycin C. Phage Umole had an icosahedral head (40 $\mathrm{nm}$ wide), a short tail (9 $\mathrm{nm}$ long) and tail fibres (15 nm long). Phage U-mole was induced with mitomycin $C$ both from bacterial cells in infection threads and from bacteroids in nodules. Southern hybridization using EcoRI fragments of phage U-mole as probe indicated that phage U-mole DNA was integrated into the chromosome of strain $\mathrm{UK}-1: \phi \mathrm{U}$ at a site involving the $6.0 \mathrm{~kb}$ EcoRI fragment of phage U-mole. Phage U-mole also lysogenized the wild-type strain $R$. leguminosarum biovar trifolii $4 \mathrm{~S}$. The resulting lysogenized strain, $4 \mathrm{~S}: \phi \mathrm{U}$, had lost its $315 \mathrm{~kb}$ Sym plasmid and its nodulation ability.
\end{abstract}

\section{INTRODUCTION}

Bacteriophages of Rhizobium (rhizobiophages) have been isolated from soils and root nodules (Demolon \& Dunez, 1935; Kowalski et al., 1974). Kleczkowska $(1950,1965)$ and Gupta \& Kleczkowska (1962) suggested a role for rhizobiophages in the evolution of ineffective rhizobial strains. Barnet (1979) and Raleigh \& Signer (1982) reported that symbiotic-defective mutants were isolated as surviving cells after exposure to specific virulent phages. They also referred to changes in other morphological and physiological properties but the mechanism of loss of symbiotic properties was unknown.

Transduction systems using lysogenic phages of $R$. meliloti or $R$. leguminosarum have been established and used to analyse Rhizobium genes (Kowalski, 1967; Finan et al., 1984; Martin \& Long, 1984; Sik et al., 1980; Buchanan-Wollaston, 1979). In addition, genetic analyses of phage 16-3, the lysogenic phage of $R$. meliloti, have been done in detail and its possibility as a useful cloning vector has been discussed (Orosz, 1973; Dorgai et al., 1981, 1986). In view of the symbiotic nitrogen fixation ability of Rhizobium, it is important to study phage gene expression in members of this genus under both free-living and symbiotic conditions.

We report here the isolation and properties of a lysogenic phage of $R$. leguminosarum biovar trifolii. Its role in symbiotic effectiveness was also assessed.

\section{METHODS}

Bacterial strains and media. Rhizobium leguminosarum biovar trifolii UK-1: $\phi \mathrm{U}$ (original host strain of phage Umole) was isolated from a nodule of a wild white clover plant (Trifolium repens) in the campus field and lysogeny detected according to Ördögh \& Szende (1960). Wild-type Rhizobium leguminosarum biovar trifolii strain 4S (Higashi \& Abe, 1980) and its derived mutants, A1 (Higashi \& Abe, 1980) and H1 (Higashi et al., 1983), were used as indicators or hosts of phage U-mole. These strains were maintained on mannitol/yeast agar slants (Keele et al., 1969). For phage induction and plasmid isolation, TY medium (Beringer, 1974) was used to avoid excess production of exopolysaccharides. Escherichia coli RR1 carrying plasmid pRt032, which has nod genes of R. leguminosarum biovar trifolii (Schofield et al., 1984) was cultured in LB medium. 
Preparation of phage $U$-mole lysates. $R$. leguminosarum biovar trifolii $\mathrm{UK}-1: \phi \mathrm{U}$ was grown at $28^{\circ} \mathrm{C}$ in $100 \mathrm{ml} \mathrm{TY}$ liquid medium to about $5 \times 10^{8}$ cells $\mathrm{ml}^{-1}$ and mitomycin $\mathrm{C}$ was added to a final concentration of $1 \mu \mathrm{g} \mathrm{ml}^{-1}$. After 6-18 h incubation at $28^{\circ} \mathrm{C}$ with vigorous shaking, $0 \cdot 5-1.0 \mathrm{ml}$ chloroform was added and incubation continued for $30 \mathrm{~min}$. Bacterial cells and cell debris were removed by centrifugation at $10000 \mathrm{~g}$ for $10 \mathrm{~min}$. The supernatant obtained was dialysed against phage buffer (Sik et al., 1980) overnight to remove chloroform.

Phage sensitivity test (spot test). Phage lysates of phage U-mole or virulent phages 4S-phage (Higashi \& Abe, 1978), and $\mathrm{kpl}$ and $\mathrm{kp} 2$, isolated from soil samples using $R$. leguminosarum biovar trifolii $4 \mathrm{~S}$ as a host, were spotted on test strains. The plates were examined for bacterial lysis after $3 \mathrm{~d}$ incubation at $28^{\circ} \mathrm{C}$.

Lysogenization of $R$. leguminosarum biovar trifolii $4 S$ with phage $U$-mole. Phage $U$-mole was spotted on plates of strain $4 \mathrm{~S}$, and incubated for $7 \mathrm{~d}$ at $28^{\circ} \mathrm{C}$. Colonies that had grown on the lytic area were isolated and purified by clonal isolation. Phage induction by $\mathrm{UV}$ irradiation $(15 \mathrm{~W}$ at $50 \mathrm{~cm}$ height for $30 \mathrm{~s})$ and immunity against phage $\mathrm{U}$-mole were demonstrated with each isolate.

Isolation of phage U-mole DNA and plasmid DNAs. Phage U-mole DNA was prepared as described by Yamamoto et al. (1970) and Dallmann et al. (1979), using polyethylene glycol 6000 and Actinase E (Kaken Seiyaku Co., Japan) followed by phenol extraction. For plasmid isolation from Rhizobium, clear lysates were prepared as described by Casse et al. (1979) except that the SDS concentration was $4 \%(w / v)$. Plasmid pRt032 was purified according to Birnboim \& Doly (1979). Prepared DNAs were digested with restriction endonucleases according to standard methods.

Agarose gel electrophoresis. Phage U-mole DNA and plasmid DNAs were analysed on $0.7 \%$ agarose gels. Electrophoresis was performed at $100 \mathrm{~V}$ for $4 \mathrm{~h}$ for restriction fragments and at $50 \mathrm{~V}$ for $14 \mathrm{~h}$ for plasmids, using TB buffer ( $89 \mathrm{~mm}$-Tris base, 2 mM-EDTA, 89 mM-boric acid, pH 8.4).

Southern hybridization. After agarose gel electrophoresis, the gels were treated with hydrochloric acid solution followed by sodium hydroxide solution. Denaturated DNAs in the gels were electrophoretically transferred to Millipore GVHP304F0 filters employing a Trans-Blot cell (Bio-Rad). Phage U-mole DNA restriction fragments were labelled with ${ }^{32} \mathrm{P}$ using the Multiprime DNA labelling system (Amersham) and used as probes. Hybridization was performed at $60^{\circ} \mathrm{C}$ for $18 \mathrm{~h}$. Then the filters were washed with SSC solution as described by Southern (1975) and autoradiographed. Southern hybridization using pRt032 as the probe was done in the same way.

Nodulation test. Nodulation and nitrogen fixation tests of strains UK-1: $\phi \mathrm{U}$ and $4 \mathrm{~S}: \phi \mathrm{U}$ were done as described elsewhere in detail (Higashi et al., 1983).

Electron microscopy. Phage specimens obtained by glycerol stepwise density-gradient centrifugation (Vande Woude et al., 1979) were negatively stained with $2 \%(\mathrm{w} / \mathrm{v})$ uranyl acetate. Nodules inoculated with strain UK-1 : $\phi \mathrm{U}$ or strain $4 \mathrm{~S}: \phi \mathrm{U}$ were observed by scanning electron microscopy and transmission electron microscopy (Higashi et al., 1986).

\section{RESULTS AND DISCUSSION}

\section{Characteristics of Rhizobium leguminosarum biovar trifolii $U K-1: \phi U$}

To obtain lysogenic strains, 15 strains of $R$. leguminosarum biovar trifolii were isolated from wild white clover nodules and tested for lysogeny using $R$. leguminosarum biovar trifolii $4 \mathrm{~S}$ as an indicator. One strain, UK-1: $\phi \mathrm{U}$, indicated lysogeny. This strain also formed effective nodules on white clover (Trifolium repens $\mathrm{cv}$. Ladino). A cell homogenate of UK-1: $\phi \mathrm{U}$ was prepared and examined by polyacrylamide gel electrophoresis. The activity staining patterns of esterase, acid phosphatase and basic phosphatase of strain UK-1: $\phi \mathrm{U}$ were very similar to those of strain $4 \mathrm{~S}$ (data not shown). A clear lysate of strain UK-1: $\phi \mathrm{U}$ was prepared and separated on $0.7 \%$ agarose gel. Three mega-plasmids, of 525, 420 and $315 \mathrm{~kb}$ were detected (see Fig. $5 a$, lane 1, and Fig. 7a, lane 2).

\section{Characteristics of phage U-mole}

Table 1 shows the host range of phage U-mole determined by spot tests using a U-mole lysate (see Methods). Phage U-mole indicated lysogeny on Rhizobium leguminosarum biovar trifolii 4S and its derived mutants $\mathrm{Al}$ and $\mathrm{H} 1$.

Electron microscopy of phage U-mole (Fig. 1) showed it to have an icosahedral head (diameter, $40 \mathrm{~nm}$ ) and a short tail (length, $9 \mathrm{~nm}$ ) resembling that of Salmonella phage P22 (Bradley, 1967) and rhizobiophage MM1H reported by Werquin et al. (1988). The tail has three parts, collar (diameter, $10 \mathrm{~nm}$ ), rigid short tail, and thin fibres (length, $15 \mathrm{~nm}$ ). The thin fibres, which have a spherical molecule at the end (Fig. $1 b$ ), may extend from the neck-collar region. 

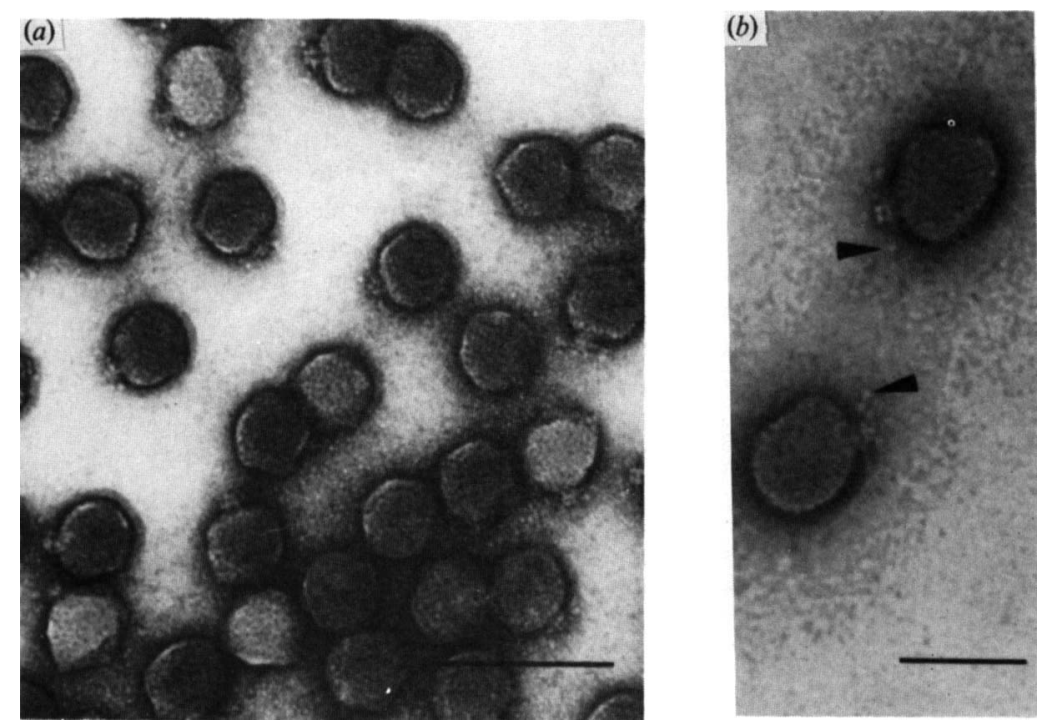

Fig. 1. Electron micrographs of lysogenic phage U-mole, negatively stained with uranyl acetate. (a) Bar, $100 \mathrm{~nm}$. (b) The arrows indicate the spherical molecule of tail fibre. Bar, $50 \mathrm{~nm}$.

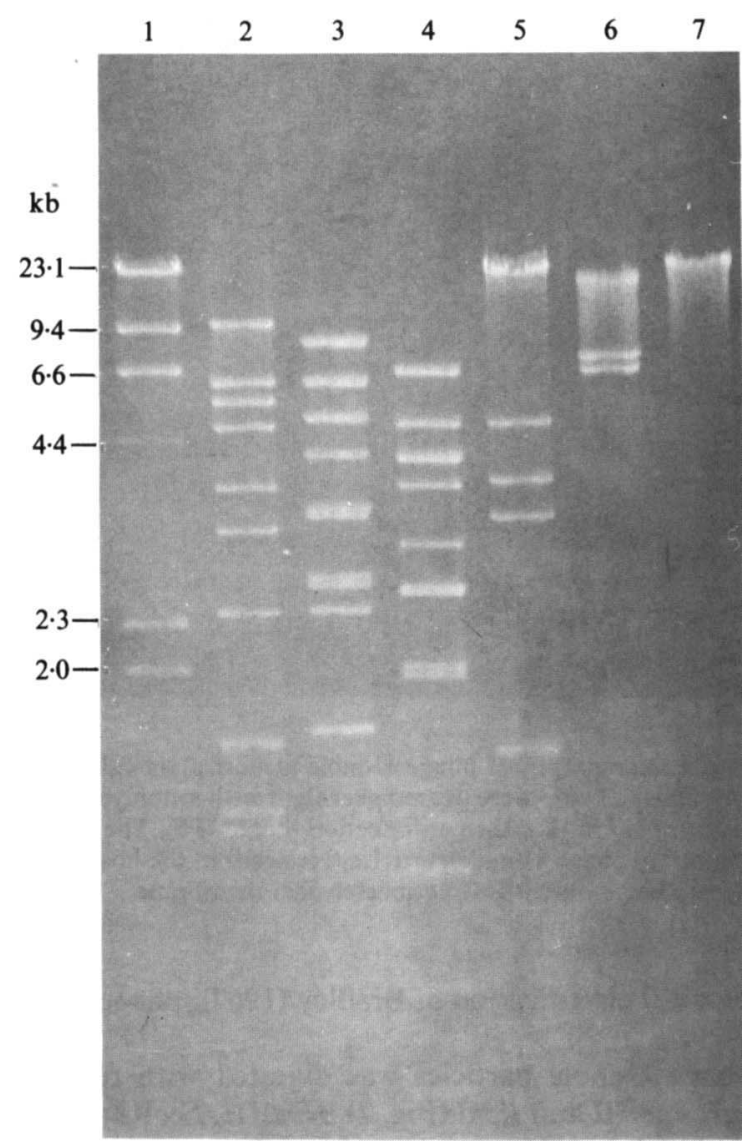

Fig. 2. Restriction endonuclease patterns of phage U-mole DNA on $0.7 \%$ agarose gel. Lane $1, \lambda$ phage DNA digested with HindIII; lanes 2-7, phage U-mole DNA digested with HindIII, EcoRI, PstI, SmaI, $B a m \mathrm{HI}$ and $\mathrm{KpnI}$, respectively. 

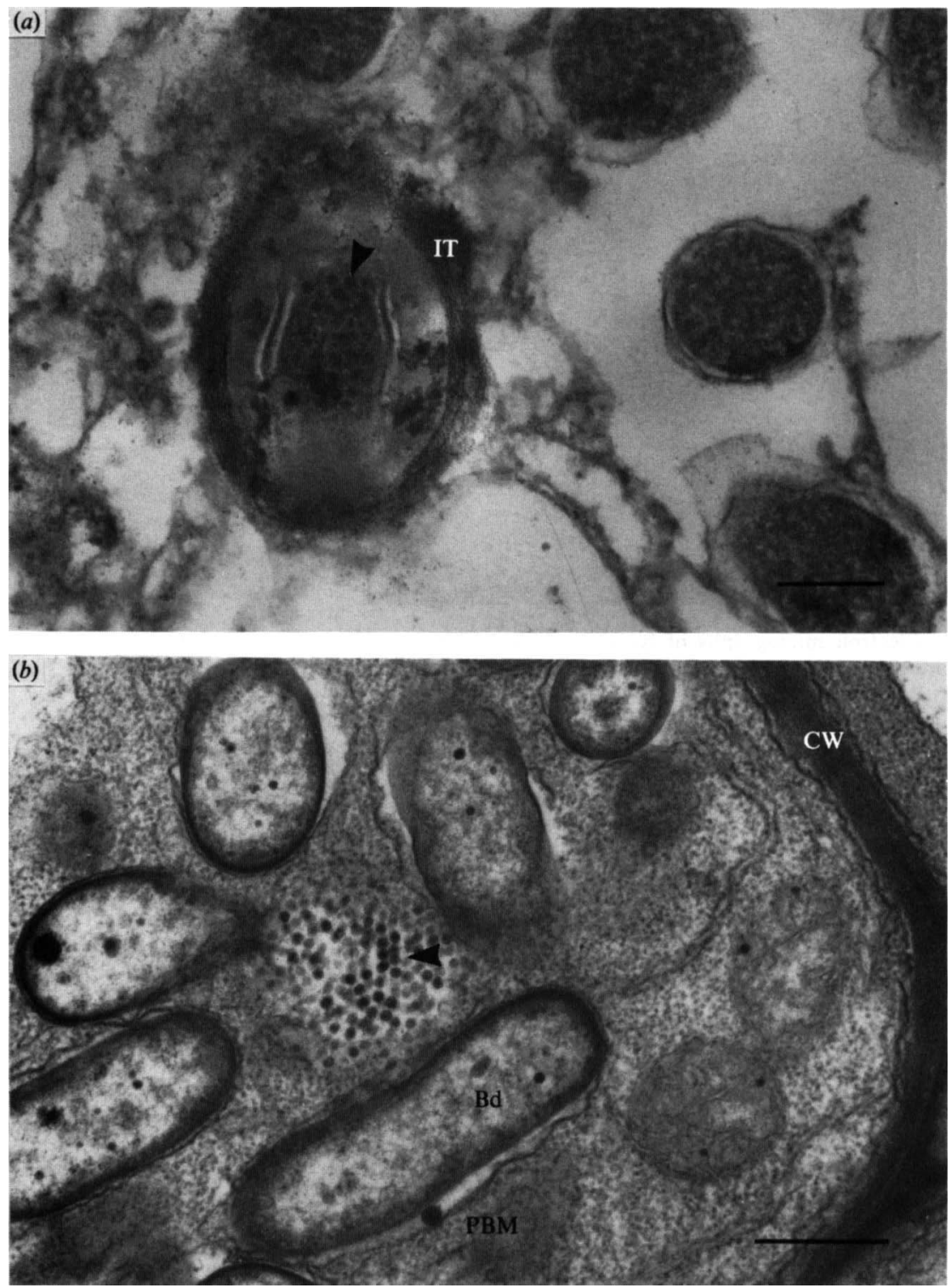

Fig. 3. Transmission electron micrographs of phage U-mole in host plant cells. Nodules formed by $R$. leguminosarum biovar trifolii UK-1: $\phi \mathrm{U}$ were treated overnight with mitomycin $\mathrm{C}$ before sectioning. (a) $R$. leguminosarum biovar trifolii $\mathrm{UK}-1: \phi \mathrm{U}$ in an infection thread (IT). The arrow indicates phage U-mole particles. Bar, $0.5 \mu \mathrm{m}$. (b) phage U-mole particles (arrowed) in the host plant cell. Bar, $1 \mu \mathrm{m}$. $\mathrm{CW}$, host plant cell wall; Bd, bacteroid; PBM, peribacteroidal membrane.

According to the morphological classification of Bradley (1967), phage U-mole is a member of group C, Podoviridae.

DNA isolated from phage U-mole particles was digested with restriction endonucleases HindIII, EcoRI, PstI, SmaI, BamHI and KpnI (Fig. 2). HindIII, EcoRI and PstI gave at least ten fragments (lanes 2-4). SmaI and BamHI gave six and four fragments, respectively (lanes 5 and 6). KpnI did not digest the DNA (lane 7). The genome size of phage U-mole was estimated from these digests to be about $40 \mathrm{~kb}$. 

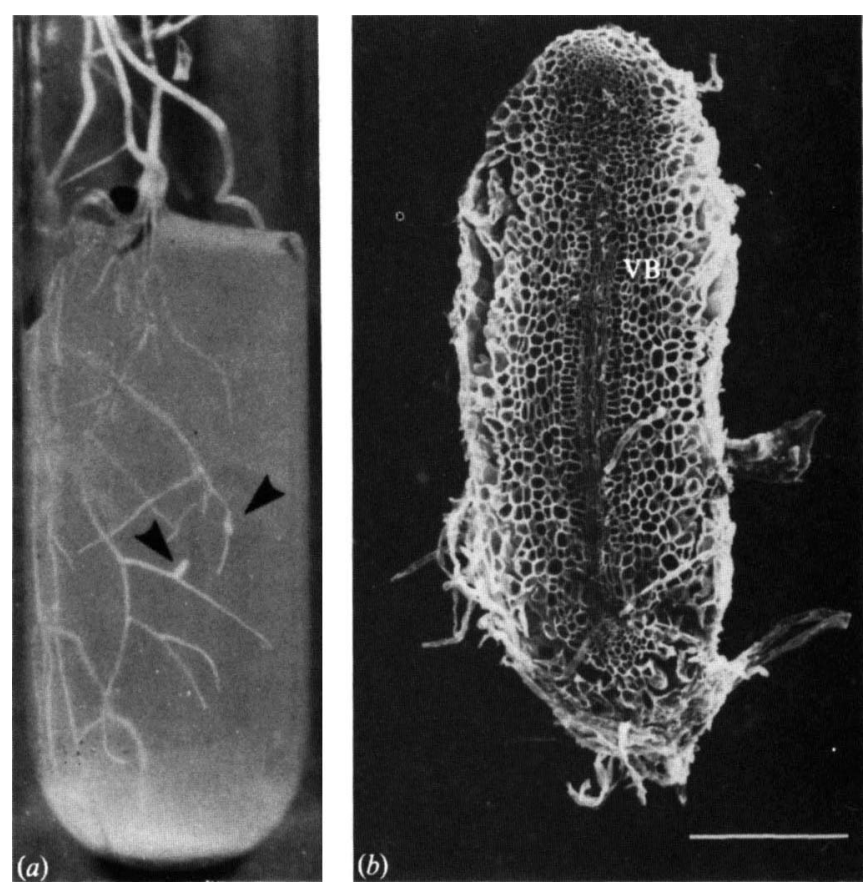

Fig. 4. Root protrusions induced by $R$. leguminosarum biovar trifolii $4 \mathrm{~S}: \phi \mathrm{U}$. (a) White clover roots inoculated with $R$. leguminosarum biovar trifolii $4 \mathrm{~S}: \phi \mathrm{U}$ after 2 months incubation. The arrows indicate root protrusions. (b) Scanning electron micrograph of a longitudinal section of the root protrusion in $(a)$. Bar, $400 \mu \mathrm{m}$. VB, vascular bundles.

Table 1. Characteristics of $R$. leguminosarum biovar trifolii strains against $U$-mole and the other virulent phages

$\begin{array}{lccccc}\text { Strain } & \begin{array}{c}\text { Lysogenic phage } \\ \text { U-mole }\end{array} & \text { 4S-phage } & \begin{array}{c}\text { Virulent phage } \\ \text { kpl }\end{array} & \text { kp2 } & \begin{array}{c}\text { Symbiotic } \\ \text { ability }\end{array} \\ \text { UK-1: } \phi \text { U } & \text { R } & \text { S } & \text { S } & \text { R } & + \\ \text { 4S: } \phi \mathrm{U} & \text { R } & \text { S } & \text { S } & \text { S } & - \\ \text { 4S } & \text { L } & \text { S } & \text { S } & \text { S } & + \\ \text { H1 } & \text { L } & \text { S } & \text { S } & \text { S } & - \\ \text { A1 } & \text { L } & \text { S } & \text { S } & \text { S } & -\end{array}$

${ }^{*} \mathrm{R}$, Resistant; $\mathrm{L}$, lysogeny; $\mathrm{s}$, sensitive.

$\dagger+$, Effective nodule formation; - , no nodule formation.

\section{Nodules formed by $U K-1: \phi U$}

The nodulation process of $R$. leguminosarum biovar trifolii $\mathrm{UK}-1: \phi \mathrm{U}$ was followed by light microscopy. As with the other $R$. leguminosarum biovar trifolii wild-type strains, root hair curling and infection thread formation were observed. Several nodules were visible on clover roots $5 \mathrm{~d}$ after inoculation. The nodulation ability of strain $\mathrm{UK}-1: \phi \mathrm{U}$ was the same as that of strain $4 \mathrm{~S}$ as to the numbers of nodules formed. These nodules were functional, as indicated by acetylene reduction ability and growth of host plants.

The nodule exudate prepared from a surface-sterilized nodule formed a large number of plaques on indicator plates. This indicates that phage induction should occur both in bacteria and in bacteroids within host plant cells. Nodules were incubated overnight at $28^{\circ} \mathrm{C}$ in sterilized water containing mitomycin $\mathrm{C}\left(10 \mu \mathrm{g} \mathrm{ml}^{-1}\right)$, then sectioned and examined by transmission 

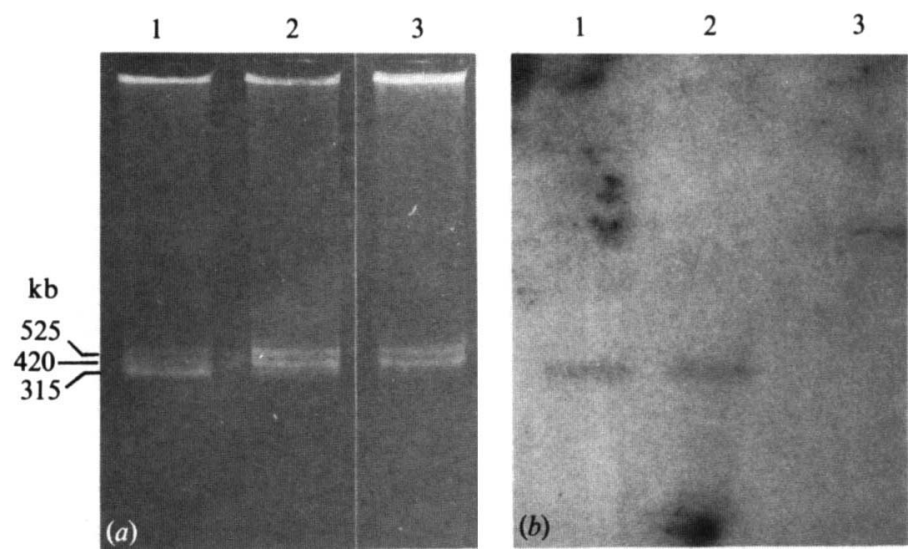

Fig. 5. (a) Crude plasmids from $R$. leguminosarum biovar trifolii strains prepared according to Casse (1979) and separated on $0.7 \%$ agarose gel; (b) Southern hybridization under stringent conditions using a HindIII digest of pRt032 as a nod probe. Lanes 1, UK-1: $\phi \mathrm{U}$; lanes $2,4 \mathrm{~S}$; lanes $3,4 \mathrm{~S}: \phi \mathrm{U}$.
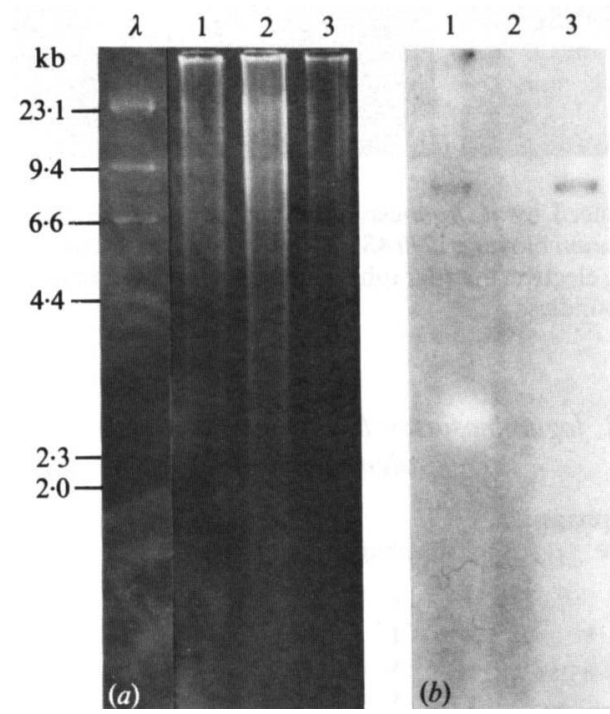

Fig. 6. (a) Restriction endonuclease patterns of $R$. leguminosarum biovar trifolii strains digested with HindIII; (b) Southern hybridization using ${ }^{32} \mathrm{P}$-labelled HindIII digest of pRt032 as a nod probe. Lane $\lambda$, HindIII fragments of $\lambda$ DNA; lanes 1 , UK-1: $\phi \mathrm{U}$; lanes $2,4 \mathrm{~S}: \phi \mathrm{U}$; lanes $3,4 \mathrm{~S} . \mathrm{A} 7 \cdot 2 \mathrm{~kb}$ fragment in $\mathrm{UK}-1: \phi \mathrm{U}$ and $4 \mathrm{~S}$ hybridized with the nod probe. No hybridization was observed with $4 \mathrm{~S}: \phi \mathrm{U}$.

electron microscopy. Rhizobium cells invade the host plant cells using infection threads, and then change their form to a bacteroid. Fig. 3(a) shows a bacterium in an infection thread and Fig. $3(b)$ shows a bacteroid surrounded by a peribacteroidal membrane. Highly electron-dense particles (arrowed in Fig. 3) were observed in both cases. In Fig. 3(b), the particles are apparently free in the host cell cytoplasm. Observation of these particles at higher magnification revealed them to be the same size and shape as phage U-mole heads. These particles appear to be phage $U$-mole. Although phage U-mole is expected to be induced spontaneously in host plant cells, the frequency of such spontaneous induction was not determined.

As phage U-mole gene expression is induced in strain UK-1: $\phi U$ under both symbiotic and free-living conditions, this phage may become a useful tool for gene transfer in a rhizobial symbiosis system. 


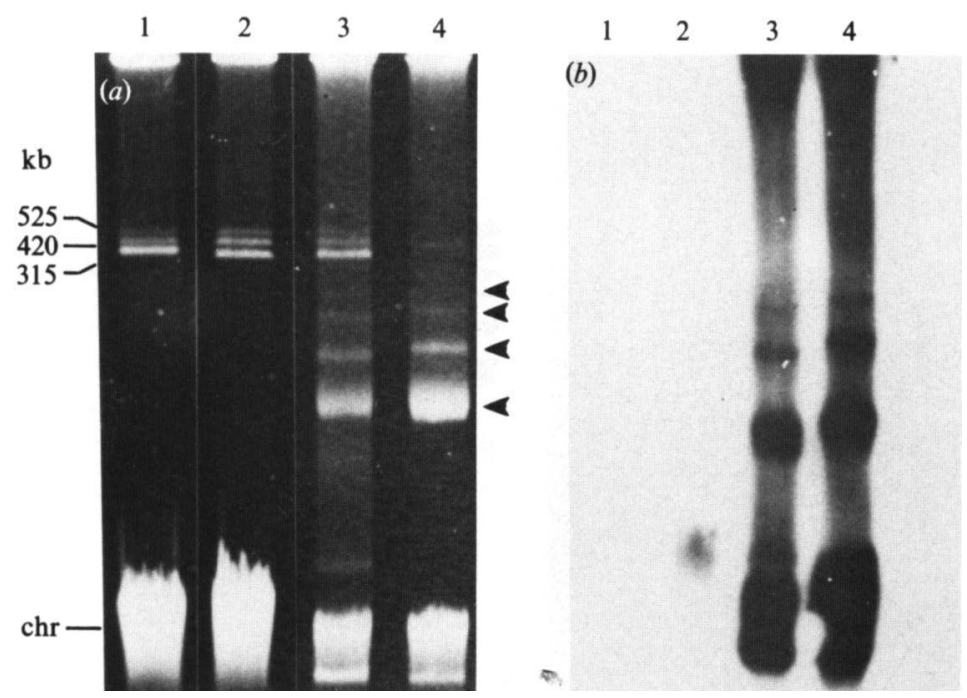

Fig. 7. (a) Crude plasmids of $R$. leguminosarum biovar trifolii strains separated on $0.7 \%$ agarose gel. The arrows indicate additional bands (see Results and Discussion); chr, fragmented chromosomal DNA. (b) An EcoRI digest of phage U-mole DNA was used as a probe for Southern hybridization. Lanes 1, 4S; lanes 2, UK-1: $\phi \mathrm{U}$; lanes $3, \mathrm{UK}-1: \phi \mathrm{U}$ incubated with mitomycin $\mathrm{C}\left(1 \mu \mathrm{g} \mathrm{ml}^{-1}\right)$ for $4 \mathrm{~h}$; lanes 4 , $4 \mathrm{~S}: \phi \mathrm{U}$.

\section{Lysogeny and symbiotic ability}

To lysogenize strain 4S, phage U-mole lysates were spotted on spread plates of strain $4 \mathrm{~S}$ (see Methods). Bacteria isolated from turbid plaques were purified and examined for lysogeny. One of these isolates, strain $4 \mathrm{~S}: \phi \mathrm{U}$, was used for further investigation.

The phage sensitivity of strain $4 \mathrm{~S}: \phi \mathrm{U}$ is summarized in Table 1 . Strain $4 \mathrm{~S}: \phi \mathrm{U}$, like its parent strain, was sensitive to all three virulent phages tested, but resistant to phage U-mole. The morphology of phages induced in strain $4 \mathrm{~S}: \phi \mathrm{U}$ by either $\mathrm{UV}$ irradiation or mitomycin $\mathrm{C}$ treatment was identical to that of phage $U$-mole. The growth rates of $4 S: \phi U$ in YM medium and TY medium were the same as those of $4 \mathrm{~S}$.

Strain $4 S: \phi U$ was inoculated onto 200 clover seedlings and incubated for about 2 months. These inoculated seedlings did not form nodules, and only two root protrusions were induced on one plant (Fig. $4 a$ ). These protrusions were very similar in shape to those described by Hirsch $e t$ al. (1985). Fig. 4(b) shows a scanning electron micrograph of a cross-section of one of the protrusions. The vascular bundles are at the centre and the cells are empty. It appeared that normal nodulation processes might have been inhibited by lysogenization, through an unknown mechanism.

\section{Hybridization analyses}

Plasmid DNAs of strains UK-1: $\phi \mathrm{U}, 4 \mathrm{~S}: \phi \mathrm{U}$ and $4 \mathrm{~S}$ were compared on agarose gel (Fig. 5). Strains UK-1: $\phi U$ and $4 S$ both carried three plasmids, of 525,420 and $315 \mathrm{~kb}$. The $315 \mathrm{~kb}$ plasmids in each strain were identified as Sym plasmids (Higashi et al., 1983). This $315 \mathrm{~kb}$ plasmid could not be detected in strain $4 \mathrm{~S}: \phi \mathrm{U}$, although the two larger plasmids were present (Fig. 5a, lane 3; Fig. $7 a$, lane 4).

It was not clear whether the Sym plasmid of $4 \mathrm{~S}: \phi \mathrm{U}$ had been cured or whether phage U-mole DNA had integrated into the nod region of the Sym plasmid. If phage U-mole DNA was integrated into Sym plasmid, the mobility of the plasmid should be decreased on agarose gel. Crude plasmid DNAs (Fig. 5) and HindIII digests of total DNA (Fig. 6) from each strain were hybridized with pRt032, as a nod gene probe. In strains UK-1: $\phi \mathrm{U}$ and $4 \mathrm{~S}$, the $315 \mathrm{~kb}$ plasmid (Fig. $5 b$, lanes 1 and 2) and a $7 \cdot 2 \mathrm{~kb}$ HindIII fragment (Fig. 6b, lanes 1 and 3) hybridized with the 


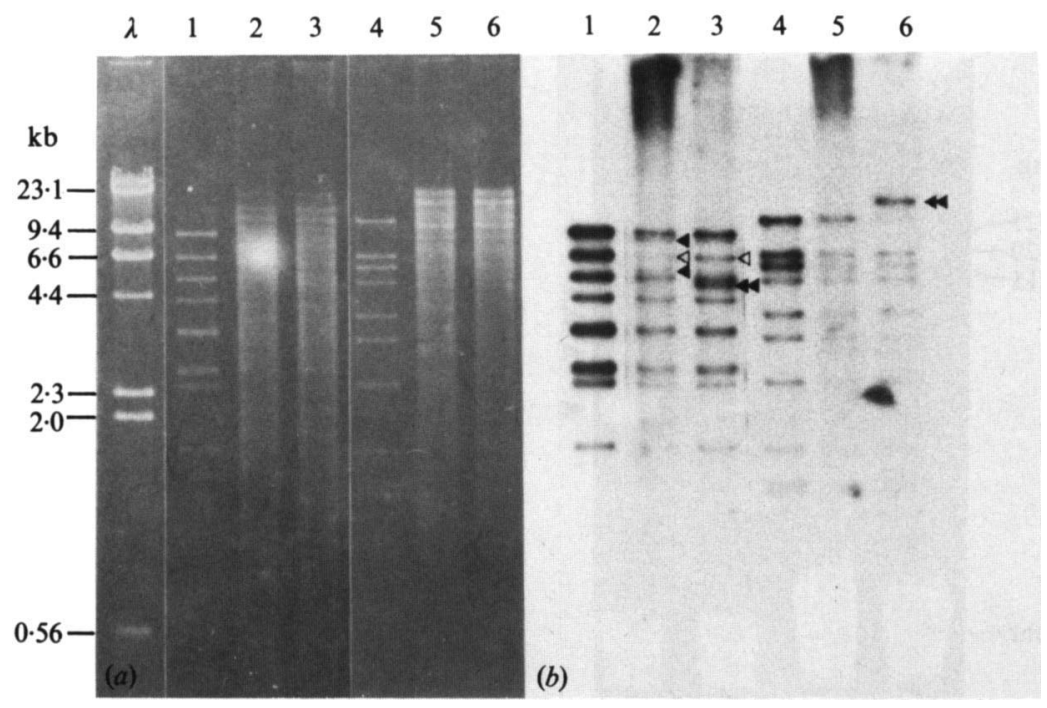

Fig. 8. (a) Restriction endonuclease patterns of phage U-mole and of $R$. leguminosarum biovar trifolii strains digested with EcoRI or HindIII. (b) Southern hybridization using ${ }^{32}$ P-labelled EcoRI or HindIII digests of phage U-mole as probe. The symbols $\varangle, \triangleleft$, and $\varangle \varangle$ are explained in Results and Discussion. Lane $\lambda$, HindIII fragments of $\lambda$ DNA; lanes 1, EcoRI fragments of U-mole DNA; lanes 2, EcoRI digests of strain UK-1: $\phi \mathrm{U}$; lanes 3, EcoRI digests of strain $4 \mathrm{~S}: \phi \mathrm{U}$; lanes 4, HindIII fragments of U-mole DNA; lanes 5, HindIII digests of strain UK-1: $\phi \mathrm{U}$; lanes 6 , HindIII digests of strain $4 \mathrm{~S}: \phi \mathrm{U}$.

nod probe. However, no hybridization was detected in strain $4 \mathrm{~S}: \phi \mathrm{U}$ (Fig. $5 b$, lane 3; Fig. $6 b$, lane 2). These results support the hypothesis that the Sym plasmid was cured in strain $4 \mathrm{~S}: \phi \mathrm{U}$.

Additional broad bands were, however, detected in strain $4 \mathrm{~S}: \phi \mathrm{U}$. These new bands (arrowed in Fig. 7a) were always detected, independent of mitomycin $\mathrm{C}$ treatment. These additional bands also appeared in UK-1: $\phi \mathrm{U}$, but only when the cells were incubated with mitocymin $\mathrm{C}$ $\left(1 \mu \mathrm{g} \mathrm{ml}^{-1}\right)$. The bands were first detected after $20 \mathrm{~min}$ incubation with mitomycin $\mathrm{C}$. Their staining intensity on agarose gel increased with increasing length of incubation time with mitomycin C (data not shown). These bands were presumed to be phage DNA. An EcoRI digest of phage U-mole DNA was labelled and hybridized with plasmid DNA of the lysogenic strains treated or not treated with mitomycin $C$ (Fig. $7 b$ ). The additional bands in UK-1: $\phi \mathrm{U}$ treated with mitomycin $\mathrm{C}$ and in $4 \mathrm{~S}: \phi \mathrm{U}$ with or without mitomycin $\mathrm{C}$ treatment all hybridized with phage U-mole DNA. In UK-1: $\phi \mathrm{U}$ not treated with mitomycin C (Fig. 7, lanes 2), the phage Umole probe hybridized with fragmented chromosomal DNA. These results suggest integration of phage U-mole into the chromosome. To investigate this further, EcoRI or HindIII digests of total DNA of UK-1: $\phi \mathrm{U}$ and $4 \mathrm{~S}: \phi \mathrm{U}$ were hybridized and compared with EcoRI or HindIII fragments of phage U-mole DNA isolated from phage U-mole particles (Fig. 8). The $7 \cdot 4 \mathrm{~kb}$ and $5.0 \mathrm{~kb}$ fragments in the EcoRI digest of strain UK-1: $\phi \mathrm{U}$ (Fig. $8 b$, lane 2, indicated by 4 ) could not be detected in the $E c o$ RI digest of U-mole DNA (Fig. $8 a, b$, lanes 1) and the $6.0 \mathrm{~kb}$ fragment in the UK-1: $\phi \mathrm{U}$ digest (Fig. $8 b$, lane 2 , indicated by $\triangleleft$ ) was very faint. These results indicate that phage U-mole DNA integrated in strain UK-1: $\phi \mathrm{U}$ chromosome at the $6.0 \mathrm{~kb} E c o \mathrm{RI}$ fragment. All three fragments were detected in the $E c o$ RI digest of strain $4 \mathrm{~S}: \phi \mathrm{U}$ (Fig. $8 b$, lane 3 ), but the $6.0 \mathrm{~kb}$ fragment (indicated by $\triangleleft$ ) was more strongly labelled than that in the UK-1: $\phi$ U digest, suggesting that phage U-mole DNA might replicate autonomously without integration into the chromosome in strain $4 \mathrm{~S}: \phi \mathrm{U}$. Furthermore, fragments characteristic to strain $4 \mathrm{~S}: \phi \mathrm{U}$ were detected (Fig. $8 b$, lanes 3 and 6 , indicated by 44). The origin of these fragments is not clear, but they may relate to Sym plasmid curing.

The molecular mechanism of Sym plasmid curing caused by lysogenization is incompletely understood. Incompatibility may occur between unintegrated phage U-mole DNA and the Sym plasmid of strain $4 \mathrm{~S}: \phi \mathrm{U}$. Lysogenic phage may also effect the symbiotic properties of Rhizobium in a manner unlike that of virulent phages. 


\section{REFERENCES}

Barnet, Y. M. (1979). Properties of Rhizobium trifolii isolates surviving exposure to specific bacteriophage. Canadian Journal of Microbiology 25, 979-986.

BERINGER, J. E. (1974). R-factor transfer in Rhizobium leguminosarum. Journal of General Microbiology 84, 188-198.

Birnboim, H. C. \& Doly, J. (1979). A rapid alkaline extraction procedure for screening recombinant plasmid DNA. Nucleic Acids Research 7, 1513-1523.

BRADLEY, D. E. (1967). Ultrastructure of bacteriophages and bacteriocins. Bacteriological Reviews $\mathbf{3 1}$, 230-314.

Buchanan-Wollaston, A. V. (1979). Generalized transduction in Rhizobium leguminosarum. Journal of General Microbiology 112, 135-142.

Casse, F., Boucher, C., Julliot, J. S., Michel, H. \& DÉNARIÉ, J. (1979). Identification and characterization of large plasmids in Rhizobium meliloti using agarose gel electrophoresis. Journal of General Microbiology 113, 229-242.

DallmanN, G., Orosz, L. \& Sain, B. (1979). Restriction mapping of DNA of temperate Rhizobium meliloti phage 16-3: comparison of genetic and physical maps indicates a long, genetically silent chromosomal arm. Molecular and General Genetics 176, 439-448

Demolon, A. \& Dunez, A. (1935). Recherches sur le rôle du bactériophage dans la fatigue des luzernières. Annales agronomiques 5, 86-111.

Dorgai, L., Olasz, F., Berényi, M., Dallmann, G., PÁY, A. \& Orosz, L. (1981). Orientation of the genetic and physical map of Rhizobium meliloti temperate phage 16-3. Molecular and General Genetics 182, 321-325.

Dorgai, L., Olasz, F. \& NÉmeth, K. (1986). Lysogenic control of temperate phage 16-3 of Rhizobium meliloti 41 is governed by two distinct regions. Molecular and General Genetics 205, 568-571.

Finan, T. M., Hartwieg, E., LeMieuX, K., Bergman, K., Walker, G. C. \& Signer, E. R. (1984). General transduction in Rhizobium meliloti. Journal of Bacteriology 159, 120-124.

Gupta, B. M. \& KLeCzKowsKA, J. (1962). A study of some mutations in a strain of Rhizobium trifolii. Journal of General Microbiology 27, 473-476.

Higashi, S. \& ABE, M. (1978). Phage induced depolymerase for exopolysaccharide of Rhizobiaceae. Journal of General and Applied Microbiology 24, 143-153.

Higashi, S. \& ABE, M. (1980). Promotion of infection thread formation by substances from Rhizobium trifolii. Journal of Applied Environmental Microbiology 39, 297-301.

Higashi, S., UchiUmi, T. \& Abe, M. (1983). Elimination of Rhizobium infectivity by temperature treatment. Journal of General and Applied Microbiology 29, 281-285.

Higashi, S., Kushiyama, K. \& Abe, M. (1986). Electron microscopic observations of infection threads in driselase treated nodules of Astragalus sinicus. Canadian Journal of Microbiology 32, 947-952.
Hirsch, A. M., Drake, D., Jacobs, T. W. \& Long, S. R. (1985). Nodules are induced on alfalfa roots by Agrobacterium tumefaciens and Rhizobium trifolii containing small segments of the Rhizobium meliloti nodulation region. Journal of Bacteriology 161, 223-230.

Keele, B. B., Hamilton, P. B. \& Elkan, G. H. (1969), Glucose catabolism in Rhizobium japonicum. Journal of Bacteriology 97, 1184-1191.

KLECZKowSKA, J. (1950). A study of phage-resistant mutants of Rhizobium trifolii. Journal of General Microbiology 4, 298-310.

KLECZKowsKA, J. (1965). Mutations in symbiotic effectiveness in Rhizobium trifolii caused by transforming DNA and other agents. Journal of General Microbiology 40, 377-383.

KowALSKI, M. (1967). Transduction in Rhizobium meliloti. Acta microbiologica polonica 16, 7-12.

Kowalski, M., HaM, G. E., Frederick, L. R. \& ANDERSON, I. C. (1974). Relationship between strains of Rhizobium japonicum and their bacteriophages from soil and nodules of field-grown soybeans. Soil Science 118, 221-228.

MARTIN, M. O. \& LONG, S. R. (1984). Generalized transduction in Rhizobium meliloti. Journal of Bacteriology 159, 125-129.

ÖRDÖGH, F. \& SZENDE, K. (1961). Temperate bacteriophages isolated from Rhizobium meliloti. Acta microbiologica Academiae scientiarum hungaricae 7, 65-71.

Orosz, L., SváB, Z., Kondorosi, Á. \& Sik, T. (1973). Genetic studies on Rhizobiophage 16-3 I. Genes and functions on the chromosome. Molecular and General Genetics 125, 341-350.

Raleigh, E. A. \& Signer, E. R. (1982). Positive selection of nodulation-deficient Rhizobium phaseoli. Journal of Bacteriology 151, 83-88.

Schofield, P. R., RidGe, R. W., Rolfe, B. G., SHINE, J. \& WATSON, J. M. (1984). Host-specific nodulation is encoded on a $14 \mathrm{~kb}$ DNA fragment in Rhizobium trifolii. Plant Molecular Biology 3, 3-11.

Sik, T., Harwath, J. \& Chatterjee, S. (1980). Generalized transduction in Rhizobium meliloti. Molecular and General Genetics 178, 511-516.

SOUTHERN, E. (1975). Detection of specific sequences among DNA fragments separated by gel electrophoresis. Journal of Molecular Biology 98, 503-517.

VANDE Woude, G. F., Oskarsson, M., EnQuist, L. W., Nomura, S. \& Fischinger, P. J. (1979). Cloning of integrated Moloney sarcoma proviral DNA sequences in bacteriophage $\lambda$. Proceedings of the National Academy of Sciences of the United States of America 76, 4464-4468.

WeRQuin, M., ACKermanN, H.-W. \& LeVesque, R. C. (1988). A study of 33 bacteriophages of Rhizobium meliloti. Applied and Environmental Microbiology 54, 188-196.

Yamamoto, K. R., Alberts, B. M., Benzinger, R., LAWHORNE, L. \& TREIBER, G. (1970). Rapid bacteriophage sedimentation in the presence of polyethylene glycol and its application to large-scale virus purification. Virology 40, 734-744. 